\title{
PHASE FEEDING IN FATTENING RABBITS
}

\author{
H. M. Abdel-Hafeez and Samar S. Tawfeek \\ Faculty of Vet. Med., Beni - Suef University, Egypt
}

\begin{abstract}
In this study two points were tried to be solved, the first was the effect of phase feeding successive diets, differing in calorie / protein ratio, on fattening performance and digestibility. The second point was the value of using high energy diets while maintaining the crude fiber at its high level. Two experiments were performed in this study, the first was the growth experiment and the second was the digestibility one.In experiment I, seven groups each of 12 weaned New Zealand White rabbits were fed according to different seven feeding regimens, three of them(group I, group IV and group VII) followed single feed program and fed diets 1 (2500 \& 17), 4 (2700 \& 18.5$)$, and 7 (2900 $\mathrm{kcal}, \mathrm{DE} / \mathrm{kg} \& 19.5 \% \mathrm{CP}$ ) while the other four groups followed the three - phase feeding system (4-7, 7-10, and 10-12 weeks of age) and fed on diets with $2500 \mathrm{kcal} / \mathrm{kg} \& \mathrm{CP} \%$ from 20 descending to 14 (group II) and from 14 ascending to 20 ( group III) and diets with $2700 \mathrm{kcal} / \mathrm{kg}$ with CP \% from 21.5 to 15.5 ( group $V$ ) and from 15.5 to $21.5 \%$ (group VI). In experiment II , the digestibility of the different diets in the three phase periods was determined where 4 rabbits were borrowed at time from its respective group. Results revealed that the feasibility of feeding high energy - high protein diets to fattening rabbits. As feed conversion efficiency was linearly improved by increasing energy and crude protein, the DE and CP were efficiently used in growth as it was clear from the figures for kcal /gain : 7.75 \& 9.91 vs. 10.56 and protein efficiency ratios :1.92 \&1.47 vs. 1.39 for $2900 \& 19.5$-, $2700 \& 18.5$ - versus $2500 \mathrm{kcal}, \mathrm{DE} / \mathrm{kg} \& 17 \% \mathrm{CP}$ -
\end{abstract}


diets, respectively. The digestibility of dry matter, crude protein, and ether extract of diet 7 was significantly higher than that of diet 1 . Comparing the single feed system with the suggested phase feeding systems indicated that beginning of fattening period on high energy and high protein - diet ( $2700 \mathrm{kcal}, \mathrm{DE} / \mathrm{kg} \& 21.5 \% \mathrm{CP}$ ) with reducing the protein level, as rabbits grew, to 18.5 and then to $15.5 \%$ led to the most efficient fattening performance. The cost of $1 \mathrm{~kg}$ gain was the final judgment. There was reduction in production cost with the suggested feeding regimes to be tested below the recommended control one .The highest cost/kg gain (about 6.4 L.E.) was recorded by group I and group IV (to some extent) while the least cost (5.03) was recorded by group $V$ with savings of about $21 \%$. The production cost of group II and group VI was in between. Although group V had the least cost, it was not distinctly different from group VII and group III. In conclusion, we recommend the three diets-system of group $V$ to be applied or the feeding system under which group III was raised when the price of oil is high or uneconomical to be added.

\section{INTRODUCTION}

In recent years there has been rising in global awareness about virtues of rabbit meat production in developing countries as an alternative means of alleviating world feed shortages. This basic understanding is largely attributable to rapid growth rate of rabbits and its good reproductive performance.

Rabbits have been raised traditionally by small farmers in Egypt to provide meat for their family and also play as a supplementary income. As most rabbit farms are not large enough to justify the use of several different feeds, it is a common practice to use just one or two diets for the entire herd, a grower diet for fryers and a lactation diet for does. Also, 
rabbit feeding programs established by NRC (1977) and Agricultural Ministry Decree (1996) have been published documentary single feed system during growing or fattening period.

Now, rabbit industry becomes more intensive and food prices are so high that any saving that can be made in intake of nutrient or food, which does not affect performance, or increasing in growth efficiency, must be worth investigating.

Cheeke (1987) stated that the nutritional requirements of rabbits, as is true for other animals, vary according to age and productive function. For optimal feeding efficiency, diets should be formulated to meet the needs of animals of a particular age or stage of production. In swine industry, for example, it is common to have a sow gestation diet, lactation diet, creep diet, starter diet, grower diet, and finisher diet, with each one balanced to meet the requirements of pigs of a given age or function. As the pigs grow, dietary energy and protein levels can be reduced without adversely affecting performance. The protein levels range from $20 \%$ for a starter diet to $15 \%$ for a grower diet and $13 \%$ for a finisher diet. Reducing the protein level as pigs grow results in substantial savings in feed cost, particularly since most of the feed in an swine operation is consumed by the growing - finishing pigs, which have the lowest protein requirements.

This was similar to what's followed in some broiler feeding system where multiple stage diets are fed basing on the assumption that amount of nutrient needed is changed as age increases. The three - phase feeding program; 0 to $3-, 3$ to 6 -, and 6 to 8 - week intervals for nutrient requirements of broilers were recommended by NRC (1994). Similar relationships were true for rabbits (Cheeke, 2005). 
Energy levels in typical rabbit diets are quite low, usually being in the range of 2400 to $2800 \mathrm{kcal} \mathrm{DE} / \mathrm{kg}$, where 2500 is recommended for growth (NRC, 1977 and Agricultural Ministry Decree, 1996) and for fattening (Agricultural Ministry Decree, 1996). Higher energy diets tend to promote microbial overgrowth in the cecum and lead to enteric disease. Thus rabbit diets usually contain alfalfa meal or other fibrous feedstuffs as the main ingredients although rabbits do not digest fiber efficiently (Cheeke, 2005).

In this study two points were tried to be solved, the first was the effect of phase feeding successive diets, differing in calorie protein ratio, on fattening performance and digestibility. The second point was the value of using high energy diets while maintaining the crude fiber at its high level.

\section{MATERIALS AND METHODS}

\section{Experimental animals and management:}

84 weaned New Zealand White rabbits of four weeks old were used for this study, which lasted eight weeks. They were obtained from a private rabbitry in Giza, Egypt. They were selected in order to constitute uniform live weight groups. All rabbits had a body weight ranging from 400 to $450 \mathrm{~g}$.

Prior to the commencement of the experiment, rabbits were prophylactically treated against internal and external parasites by subcutaneous injection of Ivermectin $(0.2 \mathrm{ml} / \mathrm{rabbit})$. Broad spectrum antibiotic (Pentomycin) was injected intramuscularly at a dose of $0.2 \mathrm{ml} / \mathrm{rabbit}$ and Cocci-4 was used as one $\mathrm{ml} /$ litter of drinking water as a prophylactic drug against coccidiosis. To guard against pasteurellosis, formaldehyde-killed vaccine $(0.5 \mathrm{ml} / \mathrm{rabbit})$ was used followed by two booster doses with four weeks intervals. 
The rabbits were housed in special rabbit metal cages each measuring 50X30X30 cm, arranged in a three tier - battery system. The system was equipped with facilities for feeding, drinking, and trays for collection of feces and urine. Rabbits were randomly allocated to seven treatments each of 12 animals. The seven rabbit groups were fed according to different seven feeding regimens forming the first experiment in which growth performance was tested. In a second experiment, the digestibility of the different diets in the three phasesperiod was determined in 21 trials using 84 rabbits, 4 in each trial, borrowed at time from its respective group. The second experiment was suggested in order to aid interpreting positive or negative results collected in the growth one.

\section{Experimental design:}

\section{Experiment I-Measuring the growth performance:}

Two experiments were performed in this study, the first was the growth experiment and the second was the digestibility one.

The experimental design could be broken into two types of treatments, the first was to test increasing the energy density and related $\mathrm{CP}$ concentration and the second related to testing the validity of phase feeding concept. The Agricultural Ministry Decree (1996) advised one type of ration for the whole period of fattening assuming that the amount of nutrient needed in each age phase remains the same throughout the whole period. The suggested phase feeding included three phase periods 4-7, 7-10 and 10-12 weeks, imitating that of broiler chicken - but after weaning, designed in order to positively push the performance by increasing $\mathrm{CP} \%$ in the early phase on the expense of the last one; and as 
a compensatory growth is expected when the $\mathrm{CP}$ is liberally allowed after a period of deficit- the $\mathrm{CP}$ in the last phase is increased on the expense of the first.

In the experiment three levels of energy densities were nominated starting with the Ministerial level $2500 \mathrm{kcal}$,DE $/ \mathrm{kg}$, increased by 200 kcal each time reaching to $2700 \& 2900$. The CP\% was increased accordingly to a round figures of 18.5 and 19.5 , keeping a $\mathrm{C} / \mathrm{P}$ ratio of $145.9 \& 148.7$ as compared to $17 \% \mathrm{CP} \& 147.1 \mathrm{C} / \mathrm{P}$ ratio in that of Ministerial recommendations . The phase protein exchange was tested with the $17 \& 18.5 \% \mathrm{CP}$ levels as the 19.5 one is too high for any increase or decrease to have an effect.

The essential amino acid methionine was kept at the same dietary level in all diets and phases as also $\mathrm{Ca}, \mathrm{P}$ and $\mathrm{Na}$ supplements and rate of adding the premix. They were suggested not to follow energy and CP concentration as they are allowances rather than needs and not to be conflicted with a deficiency of any.

In this experiment three of the seven groups followed single feed program and fed diets 1 (2500 \& 17), 4 (2700 \& 18.5), and 7 (2900 kcal, $\mathrm{DE} / \mathrm{kg} \& 19.5 \% \mathrm{CP}$ ) while the other four groups followed the phase feeding system and fed on diets with $2500 \mathrm{kcal} / \mathrm{kg} \& \mathrm{CP} \%$ from 20 descending to 14 and from 14 ascending to 20 - and diets with $2700 \mathrm{kcal}$ DE with CP from 21.5 to 15.5 and from 15.5 to $21.5 \%$.

The energy and relevant $\mathrm{CP}$ percentages were shown in the design table 1 , and the physical and chemical composition of diets in table 3 . Before formulating diets feedstuffs were analyzed for its nutrient components according to $\boldsymbol{A O A C}(\mathbf{1 9 9 0 )}$ and results were shown in Table 2. 
H. M. Abdel-Hafeez \& Samar S. Tawfeek

Table(1): Crude protein concentration in the different feeding systems used

\begin{tabular}{|c|c|c|c|c|c|c|c|}
\hline \multirow{4}{*}{$\begin{array}{c}\text { Age } \\
\text { period } \\
\text { (weeks) }\end{array}$} & \multicolumn{7}{|c|}{ Systems / groups } \\
\hline & & \multicolumn{2}{|c|}{$2500 \mathrm{kcal} / \mathrm{kg}$ diet } & \multicolumn{2}{|c|}{2700 kcal / kg diet } & \multicolumn{2}{|c|}{$2900 \mathrm{kcal} / \mathrm{kg}$ diet } \\
\hline & I & II & III & IV & V & V & VII \\
\hline & $\mathbf{C P}$ & $\mathbf{C P}$ & $\mathbf{C P}$ & $\mathbf{C P}$ & $\mathbf{C P}$ & $\mathbf{C P}$ & $\mathbf{C P}$ \\
\hline 4 4-7 & 17 & 20 & 14 & 18.5 & 21.5 & 15.5 & 19.5 \\
\hline $7-10$ & 17 & 17 & 17 & 18.5 & 18.5 & 18.5 & 19.5 \\
\hline $10-12$ & 17 & 14 & 20 & 18.5 & 15.5 & 21.5 & 19.5 \\
\hline
\end{tabular}

$\mathrm{DE}$, digestible energy, is expressed in $\mathrm{kcal} / \mathrm{kg}$ diet while $\mathrm{CP}$, crude protein, in\% .

Growth patterns of the rabbits were determined by weighing them individually every week early in the morning before feeding over a total period of 56 days to determine weight gain. The intake of feed was determined weekly by weighing amounts offered and refused.

Feed intake, weight gain, feed conversion efficiency (FCR) and protein efficiency ratio (PER) were monitored, following the equations cited by MacDonald et al. (1990)

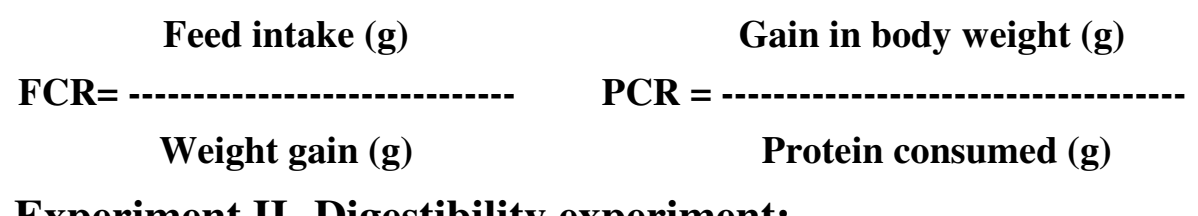

\section{Experiment II- Digestibility experiment:}

During the last week of each feeding stage $\left(7^{\text {th }}, 10^{\text {th }}\right.$ and $12^{\text {th }}$ week) four rabbits from each group were transferred to wire cages that were equipped to adapt separate collection of fecal matter and urine by using fishing net hanged underneath each cage. Total daily feces voided were collected every morning from each animal for successive five days, weighed and kept in deep freezer. At the end of the five day - collection period, feces were bulked together, thoroughly mixed, oven dried and kept frozen for analysis. 
Feed intake was fixed at the least intake, recorded in the first two days of the last week of each feeding stage. The daily amount allowed for each rabbit was divided into two meals, one half in the morning and the other one in the evening to reduce wastage. Feed consumption was recorded over the five days of collection period. Unconsumed feeds were collected from each animal and weighed every day in the morning before fresh feed was served.

Samples of previously bulked unconsumed feeds and feces that predried at $60^{\circ} \mathrm{C}$ for 48 hours before grinding were taken for chemical analysis to determine approximate composition, DM; CP; EE; ash and CF. Digestibilities of the dry matter or its nutrients were estimated using the following equation according to McDonald et al. (1990):

Dry matter or nutrient digested

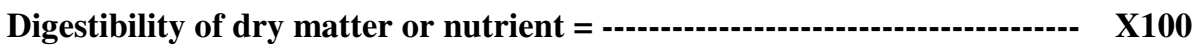

Dry matter or nutrient intake

\section{Statistical analysis:}

The data were analyzed statistically using the INSTAT to calculate the mean, standard error and the significance among figures was tested using Student " $t$ " test.

\section{RESULTS AND DISCUSSION}

\section{Animal performance:}

\section{One feed system with different energy densities:}

The groups I, IV and VII were treated by the one diet - system allover the eight weeks of the fattening period. The diets were of 2500 $\mathrm{kcal}, \mathrm{DE} / \mathrm{kg}$ and the protein of $17 \%$ in the first group, and with respective figures of $2700 \& 18.5$ and $2900 \& 19.5$ in the other two groups. Referring to table 5 the weekly weight gain was 220, 247 and 306 in a 
respective order, a result which pointed to the feasibility of feeding high energy-high protein diets to fattening rabbits. According to Lebas (1983) the DE content of the diet was one of the main factors affecting the level of feed intake in rabbits. Forbes (1995) and Xiccato (1996) reported that the reduction of DM intake happened when feed of a higher dietary energy value was given, was as a consequence of the chemostatic regulation of appetite. These results agreed with our results where the rabbit consumed $132.5 \mathrm{~g} /$ day in group I decreased to 129.5 in IV and 116.8 in VII. For a unit of body gain a decreased amount of feed is needed as the energy density increased where the feed conversion index in the three groups was 4.22, 3.67 and 2.67. Maertens and De Groote (1987) found a linear relationship between feed conversion ratio \& digestible energy content of diets, for commercial rabbits from 4 to 11 weeks of age. The precise limits of this ratio were not clear. As feed conversion efficiency was improved by increasing energy and crude protein, the DE and CP were efficiently used in growth as it was clear from the figures for $\mathrm{kcal} /$ gain $(10.56$ versus $9.91 \& 7.75)$ and protein efficiency ratios (1.39 versus $1.47 \& 1.92)$.Comparing these results with the study of Lebas (1975 a) on the performance of growing rabbits fed diets differing in energy content, indicated that there was disagreement because they found that about $9.5 \mathrm{kcal}$ of DE was required per gram of body weight gain, regardless of energy content of the diet . Conclusively the cost of body weight gain decreased from $6.42 \mathrm{~L} . \mathrm{E} / \mathrm{kg}$ gain with the 2500 kcal-diet to 6.36 and 5.14 in the $2700 \& 2900 \mathrm{kcal}$, respectively.

\section{The three - phase systems:}

In order to compare the data of phase feeding - groups with that of group I, the figures were arranged in three phase periods even in the first group in which one diet-system was used considering it a control for comparison. 


\section{Diets with 2500 kcal, DE / kg:}

\section{Phase I (4 -7 weeks):}

The crude protein percentages in a respective order were of 17, 20, and 14 units while the energy was fixed at $2500 \mathrm{kcal}$. The increase in body weight followed the percentage of protein where it was $600 \mathrm{~g}$ with the $17 \%$, increased to 654 with $20 \%$ and decreased to $522 \mathrm{~g}$ with 14( Table 4 ). The increase in body weight did not compare well with units increased or decreased in protein. It was an increase of $2.6 \mathrm{~g} / \mathrm{d}$ and a decrease of $3.7 \mathrm{~g}$ on the other side. On the reverse increasing the CP from 17 to 20 decreased feed intake by $68 \mathrm{~g}$ in the 3 weeks and improved the feed conversion index from 3.3 to 2.92 while decreasing the protein to $14 \%$ increased feed intake by $168 \mathrm{~g}$ and the feed conversion retreats from 3.3 to 4.1 .

\section{Phase II (7- 10 weeks):}

The three groups were fed the same diet having $2500 \mathrm{kcal}, \mathrm{DE} / \mathrm{kg}$ and $17 \% \mathrm{CP}$, and in spite of this phase I - high $\mathrm{CP}$ still has a continued effect, it increased the body gain by $76 \mathrm{~g}$, decreased feed consumption by $380 \mathrm{~g}$ and improved feed conversion ratio from 4.26 in group I to 3.41 .On the other side allowing the animals high - protein diet (17\%) after a phase of protein deficit in group III did not have the increasing effect on feed intake but on the reverse a decreasing one ( a decrease of $754 \mathrm{~g}$ ) but on the other hand improved greatly the feed conversion from 4.26 to 2.79 , a score in excess of group II ( Table 4). This was because the weight gain in group III surpassed that of group II by $51 \mathrm{~g}$ in the three weeks period. 


\section{Phase III (10 -12 weeks):}

The effect of phase I - $20 \% \mathrm{CP}$ - diet (group II) continued in the third phase in spite of decreasing the protein to $14 \%$, but with a small improvement in body gain ( $58 \mathrm{~g}$ ) and feed conversion index (5.01 versus 5.52 in group I) and feed intake, on the reverse, slightly increased (83 g) .In group III where protein was increased to $20 \%$ in order to compensate the phase of protein deficit, it highly increased the gain (600 versus $405 \mathrm{~g}$ in group I) and improved the feed conversion to the degree that $3.74 \mathrm{~kg}$ feed is needed for $1 \mathrm{~kg}$ body gain compared to $5.52 \mathrm{~kg}$ food in the first group. This could be explained by the report of Lawrence and Fowler (1997) that rabbits exhibited compensatory growth during the recovery period where their growth rate accelerated and exceeded those achieved by comparable animals fed well and continually.

\section{The total fattening period (4 -12 weeks):}

Comparing the three systems together clarified that group III won and giving animals a diet deficient in protein for 3 weeks, then the protein increased gradually to $20 \%$ give more body gain by about $14 \%$ and decreased food needed for $1 \mathrm{~kg}$ gain by $19 \%$. Increasing protein concentration in phase III in which the animal consumed about $33 \%$ of the total feed intake in the whole fattening period means increasing the cost of production. One $\mathrm{kg}$ of a diet of $20 \% \mathrm{CP}$ costs $1.62 \mathrm{~L}$.E. compared to 1.52 for the $17 \% \mathrm{CP}$ and 1.43 for the $14 \%$ one. In spite of this, the cost of $1 \mathrm{~kg}$ gain was the final judgment; it was $6.42,5.51 \& 5.22$ for the three groups respectively with the third group surpassing (Table 5). So planning for a compensatory growth by limitation followed by liberal allowance was better than increasing protein percentage over the needed level to push rate of growth. 


\section{Diets with 2700 kcal, DE / kg:}

While the level of energy was fixed at $2700 \mathrm{kcal}$ allover the fattening period, the protein concentration was decreased from $21.5 \%$ in phase I to 18.5 in phase II to 15.5 in phase III for group V and was increased from 15.5 to 18.5 and to $21.5 \%$ for group VI in the three successive phases.

\section{Phase I (4 - 7 weeks):}

The data illustrated in table 4 showed that there was slight but significant decrease in body weight of group VI compared with group I which translated in insensible decrease in its body gain (595 vs. $600 \mathrm{~g}$ ). The high energy and high protein - diet caused significant increase in body weight of group V (1182 versus $1046 \mathrm{~g}$ for G I) which gained more weight $(25 \%)$ than did those of group I. The superiority of group V in gain of weight was not associated with the least feed intake among groups but when the amount consumed was attributed to gain they had the most efficiency of feed utilization $(2.55,3.14 \& 3.30$ in $\mathrm{G} \mathrm{V}, \mathrm{G}$ VI , $\&$ G I , respectively) .

\section{Phase II (7 -10 weeks):}

The control group behaved the same trend that followed in phase I where it had the least gain ( 752 g compared with 844 and 921 in G V and GVI ) which cost much more feed at the rate of about $4.3 \mathrm{~kg} / \mathrm{kg}$ gain versus 3.06 in GV \& 2.83 in G VI . The high - protein diet (18.5\%) after a phase of protein deficit in group VI led to the most efficient performance in the form of the highest gain in weight and the best feed conversion ratio which reflected in the most efficient utilization of the digestible energy and protein $(7.63 \mathrm{kcal}$ vs. $10.65 \& 8.25$ and 1.91 vs. $1.38 \& 1.77$, in groups I and V, respectively). 


\section{Phase III (10 - 12 weeks):}

The effect of phase I - 21.5\% CP - diet ( group V) continued in the third phase in spite of decreasing the protein to $15.5 \%$, with a highly improvement in body gain (265 g), feed conversion index (3.15 versus 5.52 in group I) and protein efficiency ratio (2.05 vs. 1.06) and the lower intake of feed and of DE required for each gram of body gain $(151 \mathrm{~g} / \mathrm{d} \&$ $8.49 \mathrm{kcal}$ and $160 \& 13.81$ in GV \& G I, respectively). Generally this group achieved the most efficient performance among treatments. In group VI where protein was increased to $18.5 \%$ in order to compensate the phase of protein deficit, it highly increased in gain(636 versus $405 \mathrm{~g}$ in group I) and improved the feed conversion to the degree that $3.53 \mathrm{~kg}$ feed was needed for $1 \mathrm{~kg}$ body gain compared to $5.52 \mathrm{~kg}$ food in the first group.

\section{The total fattening period ( 4 to 12 weeks):}

Results presented in table 5 demonstrated the fattening performance of rabbits groups raised under different feeding systems during the whole fattening period. The data clarified that the start of rearing rabbits for fattening on high protein and high energy- diet (2700 kcal DE \& $21.5 \%$ $\mathrm{CP})$ with gradual and periodical reduction in protein level as rabbits grew ( GV) increased the gain by about $29 \%$ and decreased feed required to produce $1 \mathrm{~kg}$ gain by $11 \%$. Also the VI - phase feeding program succeeded to achieve improvement in gain by about $22 \%$ and to reduce the amount of feed needed per $1 \mathrm{~kg}$ gain to3.12 versus to 4.22 in group I.

\section{Economical efficiency:}

Comparison between the recommended Ministerial feeding system for fattening rabbits and the suggested ones was based on the feed economy which considered as a preferential point .The cost to produce 
one kilogram of each diet was presented in Table 4. Increasing the protein or /and energy contents of the diets led to increase in feed cost due to increase the inclusion levels of soybean meal and the addition of oil in diets. The cost of one percent unit of protein over that of control diet were 0.035 L.E. and about 0.158 L.E. for each $200 \mathrm{kcal}$ increase in DE concentration above $2500 \mathrm{kcal}$.

From an economic standpoint, there was reduction in production cost with the suggested feeding regimes to be tested below the recommended control one .The highest cost $/ \mathrm{kg}$ gain (about 6.4 L.E.) was recorded by G I \& G IV (to some extent) while the least cost (5.03) was recorded by $\mathrm{G} V$ with savings of about $21 \%$. The production cost of $\mathrm{G}$ II and G VI was in between. Although G V had the least cost, it was not distinctly different from G VII\& G III.

\section{Digestibility coefficients:}

\section{Dry matter digestibility:}

The total digestibility of dry mater consumed by control group during the total feeding period was poorer than the others except group III .It showed significant difference from group II at $7 \& 10$ weeks of age (69 \& 72 vs. $79 \& 81 \%$, respectively) and from group V at $12^{\text {th }}$ week (69 vs. $80 \%$ ). The highest efficacy of DM digestibility (85\%) was achieved by group VII which highly significantly differed from control group at the three age- periods (about 1.2 times). This was attributed to the reduction of DM intake, which occurred with feed of a higher dietary energy value, was associated with a lower transit time of digesta and consequently led to increased digestion efficacy (de Blas \& Wiseman, 1998). 


\section{Crude protein digestibility (CPD):}

It is commonly accepted that an increase in the CP content of feedstuff increases its crude protein digestibility because the proportional contribution of endogenous nitrogen to total fecal nitrogen decreases (de Blas and Wiseman, 1998). The data of our study which was shown in table 6 confirmed this report where the digestibility of CP by the control group in phase I was of percent units lower than that of higher proteindiets by about 2 to 13 . Also crude protein digestibility (CPD) increased when rabbits were transferred from low protein to high protein-diet as in group III. All over the fatting period, control group digested protein with the least efficacy while the most efficient protein digestibility was achieved by GVII.

\section{Ether extract digestibility (EED):}

The digestibility of EE ranged from $63-65 \%$ in the three non added fat groups (G I, G II \& G III) while with addition of about $4 \%$ fat the digestibility coefficient increased reaching to average of 0.79 among G IV, G V, and G VI . The increase of the inclusion level to $7 \%$ highly significantly improved the digestibility by $22 \%$ than the control group. The same observation was previously recorded by Maertens et al.(1986) where EED of a non - added fat diet which contained 2.5-3\% of structural lipids linked to vegetable cell walls, was rather low (0.450.65). In three diets with $0,3 \& 6 \%$ added fat, Santoma et al. (1987) observed a significant increase in EED as fat level increased $(0.64,0.75$ \& 0.79 respectively) without any significant difference between fat 
sources. These data was confirmed by Fernandez et al. (1994) using diets with different types of fat (beef tallow, oleins or soybean oil) and inclusion levels (3\& 6\%). These authors found EED of 0.48 for a conventional non-added fat diet, $0.71-0.76$ for $3 \mathrm{~g}$ and $0.80-0.83$ for $6 \%$.

The digestibility efficiency for fat, as well as for other nutrients seemed to vary during the life of rabbit. Digestion coefficient of different nutrients tended to either decrease or remain constant with age, but EED seemed to follow a different trend. The range of lipid digestibility values was $59-62 \% \& 71-83 \%$ at $7^{\text {th }}$ week of age and rose to become $66-67$ and $77-88 \%$ at $12^{\text {th }}$ week for the first three group of non added fat and the rest treatments of fat addition, respectively. Evans and Jebelian (1982) observed increasing EED from 0.78 at 5 weeks to 0.82 at 8 weeks. Xiccato and Cinetto (1988) confirmed these results with EED rising from 0.72 (7 weeks) to 0.79 (12 weeks), on the other hand, Fernandez et al. (1994) observed higher EED values in recently weaned rabbits ( 5 weeks) than in finishing rabbits (10 weeks).

\section{Crude fiber digestibility}

There were no significant differences among treatments in digestibility of crude fiber.The values ranged from $16 \%$ in control group to about $20 \%$ in Group VI. Slight improvement in CF digestibility was observed with groups fed high energy diets.

\section{CONCLUSION}

From the data of fattening performance, digestibility, and economical efficiency we can recommend the three diets-system of $\mathrm{G} \mathrm{V}$ to be applied or the feeding system under which group III was raised when the price of oil is high or uneconomical to be added. 


\section{REFERENCES}

- Agricultural Ministry Decree. (1996). Ministerial Decree No. 1498, 1996 for Regulation of feeds and its Manufacturing, Manipulation, and Control issued in Egyptian Bulletins-1997. Vol. 192 (related) .pp 105. Ministry of Agriculture, Egypt.

- AOAC. (1990). Association of Official Analytical Chemists. Official Methods of Analysis. $5^{\text {th }}$ Revised Edition. Washington. D.C .

- Cheeke, P.R. (1987). Rabbit Feeding and Nutrition. Academic Press, Orlando, Florida.

- Cheeke, P.R. (2005). Applied Animal Nutrition. Feeds and Feeding $3^{\text {rd }}$ Edition.

- de Blas, C. and J. Wiseman. (1998). The Nutrition of the Rabbit. CAB International.

- Evans, E. and V. Jebelian. (1982). Effects of age upon nutrient digestibility by fryer rabbits. Journal of Applied Rabbit Research. 5:8-9.

- Fernandez, C., A. Cobos, and M.J. Farag. (1994). The effect of fat inclusion on diet digestibility in growing rabbits. Journal of Animal Science. 72:1508-1515.

- Forbes, J.M. (1995). Voluntary Feed Intake and Diet Selection in Farm Animals. CAB Int., Wallingford, UK.

- Lawrence. T.L.J. and V.R. Fowler. (1997). Growth of farm animals. pp.219 CAB Int.

- Lebas, F. (1975 a). Influence of the dietary energy content on the growth performance of the rabbit. Ann. Zootech. 24:281-288. 
- Lebas, F. (1983). Small-Scale rabbit production feeding and management. World Animal Review. 46:10-17.

- Maertens, L. and G. De Groote. (1987). Quelques. caracteristique specifiques de l'alimentation des lapins. Revue de I'Agriculture 40:1185-1203. In: de Blas, C. and J. Wiseman (1998) The Nutrition of the Rabbit. CAB. Int.

- Maertens, L., G. Huyghebaent, and G.De Groote. (1986). Digestibility and digestible energy content of various fats for growing rabbits. Cuni - Science. $3: 7-14$.

- McDonald, P., R.A. Edward, and J.F.D. Greenhalgh. (1990). Animal Nutrition. $4^{\text {th }}$ Edition.

- National Research Council.(1977). Nutrient Requirements of Rabbits. $2^{\text {nd }}$ Revised Edition. Washington. D.C.: National Academy Press.

- National Research Council.(1994). Nutrient Requirements of Poultry. $9^{\text {th }}$ Revised Edition. Washington. D.C.: National Academy Press.

- Santoma, G., J.C.de Blas, R. Carabano, and M.J. Fraga. (1987). The effects of different fats and their inclusion level in diets for growing rabbits. Animal Production. 45:291-300.

- Xiccato, G. (1996). Nutrition of lactating does. In: Lebas, F. (ed) Proceedings of the World Rabbit Congress. 1:29-50.

- Xiccato, G., and M. Cinetto. (1988). Effect of nutritive level and of age on feed digestibility and nitrogen balance in rabbit. Proceedings of the $4^{\text {th }}$ World Rabbit Congress.Vol.3. Sandor Holdas Hercegalom, Budapest, pp.96-103. 


\section{التفذية المرحلية في أرانب التسمين}

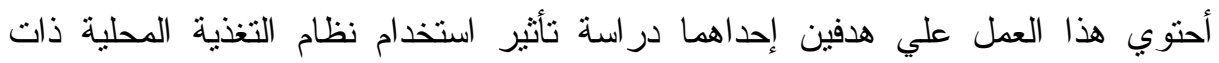

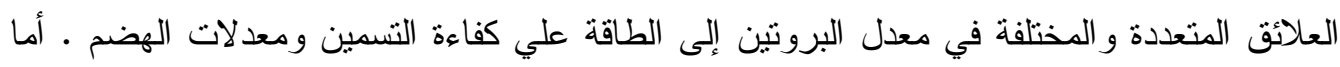

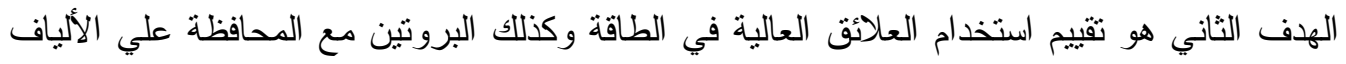

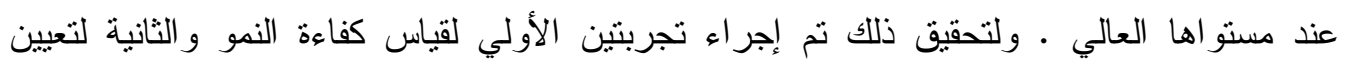

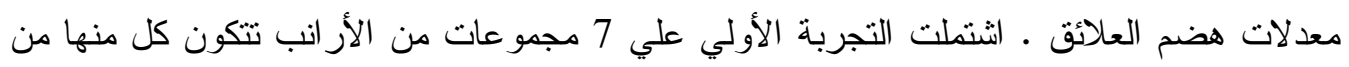

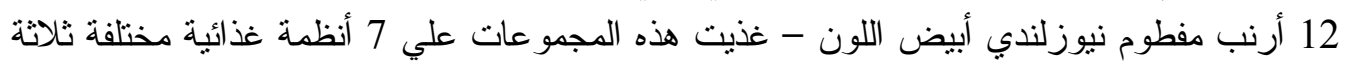

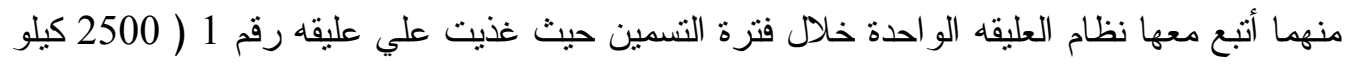

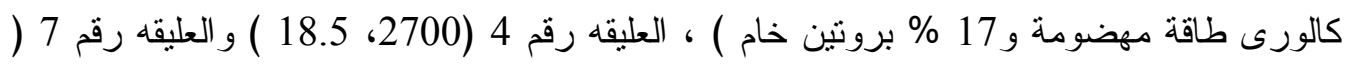

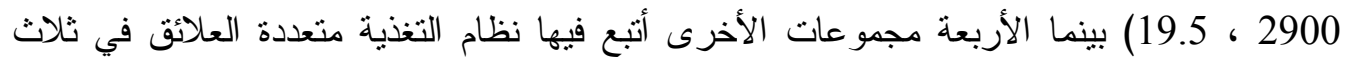

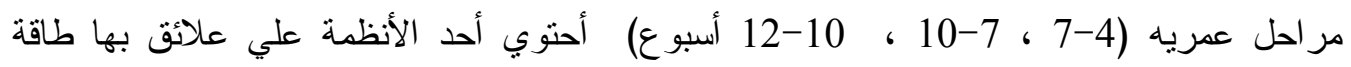

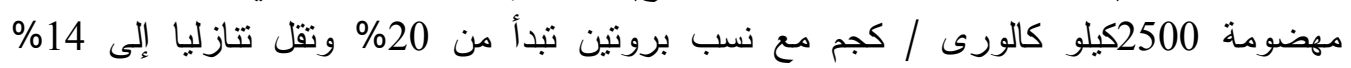

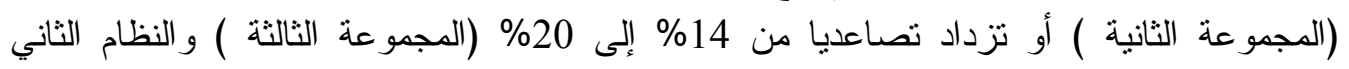

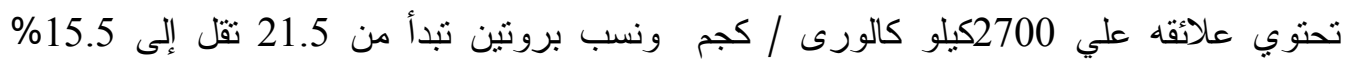

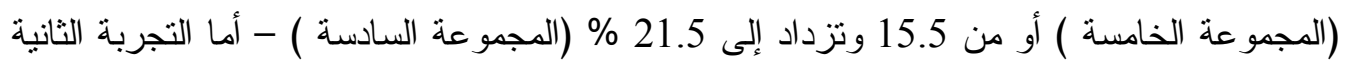

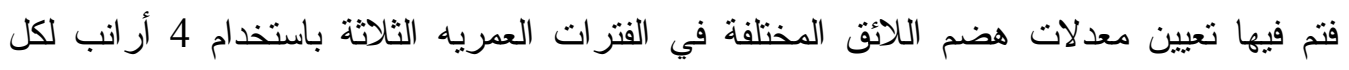

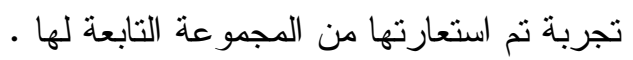

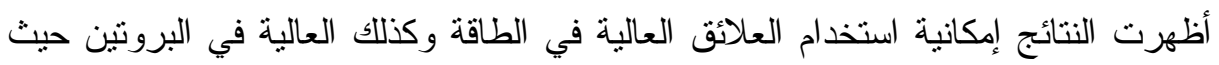
تحسنت معدلات التحويل الغذائي كلما زاد مستوي الطاقة و البروتين في العلائق كما كانت أعلى العلي

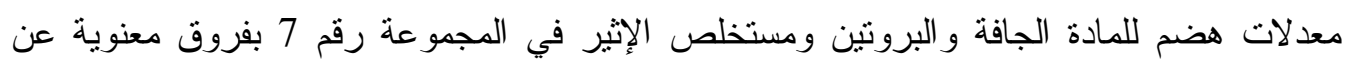

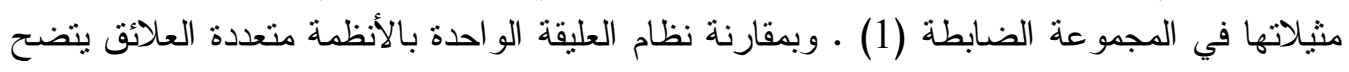

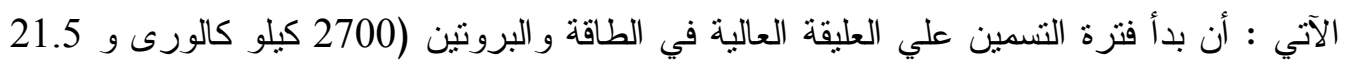

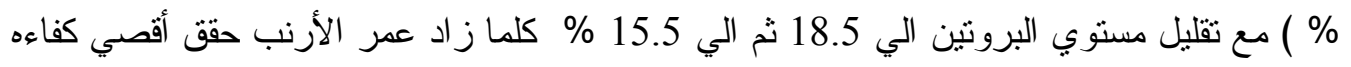

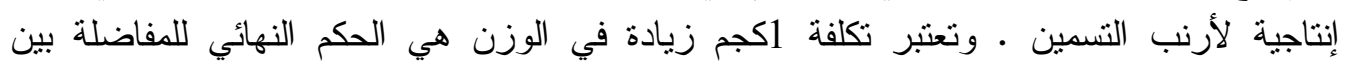

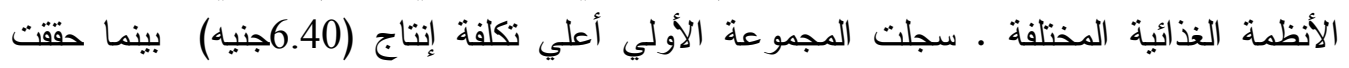
المجموعة الخامسة أقل تكلفة (5.03 جنيه) و التي لم تزيد زيادة واضحة عن الأنكة التكلفة في المجموعات الثالثة و السابعة .

وبذلك نوصي باستخدام نظام الثناث علائق المطبق في المجموعة الخامسة في تسمين

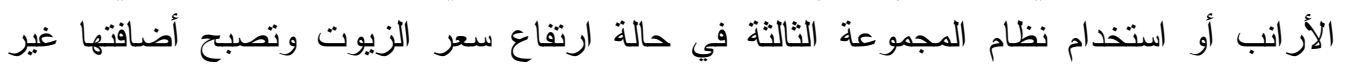
|قتصادية. 